域のにっ8 分

社意、た当野戦

会義か問初に前

学にえ題のおの

の立っ状課い国

立 5 況題 $\tau 民$

場返混のに\&生

加り乱8応、活

ら、がとえ 幾研

はなた明歴消造

じっ地ら史費論生

めた域か的都で活

に 生のに展市は構

活歴な開・、造

ス史つを松こ論

ことま、ものに

のつつ同の業端

夕的た气阪れ戊

問のたじに績を

イ特。てのます

題事感くはを発

を例が生す

ル殊つき事で本

を性ま例こ来

考研あ生らんる

え究る活なで生

たは、、結研ら

に都生とにつ々

み題本造つた構

た材稿造た。造

いに、での。し論

都念念しかは

蒂生がろ、そ

社活語そそ挠

会構語 そ卆後

な論れつは社

いのたど必会

し本た異ず学:

地来めなしの

呼吽がすら息 出

ん告存るず律のしか

だ活在之必性回たつ

の骨しい要を復のて

で組でった

犬ே こ

くを㪨この生中

すは示い時とに活鉢

なはしず間で還が正

わ集てれがあ元単美

ち、団いも確つでにが

そ的た生さ保たる労生

生市活しもたの

出の自てと銛銛

すも律そきのに

うの性の、自経

えのは地地律済

で工、域地性的

、コそに域の構

豊口れ保社造

か湆を持と会か

な力歴さ関学 ら

素儿史れ算的の

材な的て連な二

を展にきで根定

提開とたこ拠の

供にら文間に自

すよえ化䦗つ律

るってシ題い性

むて は希考て 方

で年め允市十る

あ出てやて分こ

るさ明地みなと

れら域た検に

るか組々討 注

のに織そが目

ですのの行し

ある特結わた

つこ殊果れ文

てとないの

、が形集きで

れ心そ活れ労も淮時

は理うにな衝のの間

人的いはい時で再調

々シっそと間は生查

のスたれかがな産や

自六自、延く它生

律么定体エび、か、活

的しのひンてそ、費

側を自をゲもれ肉調

面、律つル余自体査

を生性の係暇体的に

捉活を構数時、工お

え構も造が間一ネい

た造つ的湾が定ルて

概とた枠曲減のギ見

産で態异たあ

業きに生とっ

主るよ活はた。

義のでて戛言し

なあ、律なか

ラる。支性いし

フそら 本 社

スしれ町稿会

タててごで学

イ、いとは的

ルそるに、な

とらこ固伝生

はいと有統活

異っがの型構

玉

野

和

志 


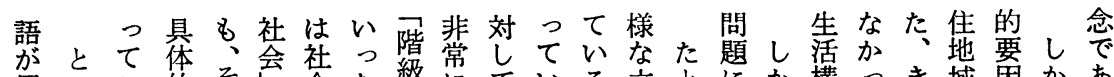

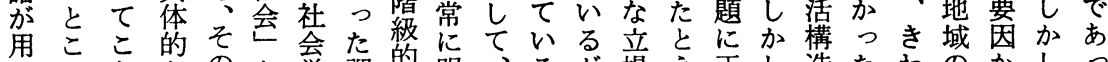
いろななのと学調に的、るが暘え正し造たわのかしっ $ら$ で調意い的子に確資。かば面、論のめ環ら、た

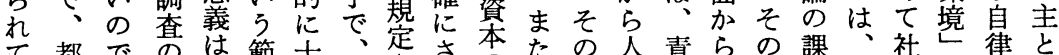
て都での

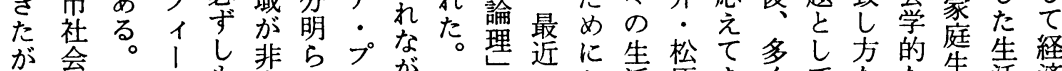

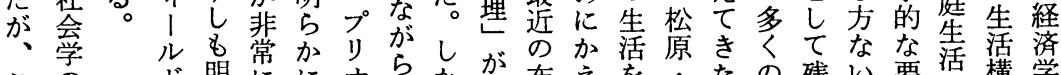

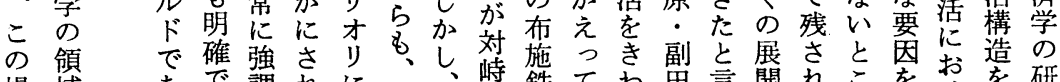

場域あで調れにこ、峙鉄てわ田言開れこをおを研

合でるはさて前こ肝さ治、めにえをたるあるる替究

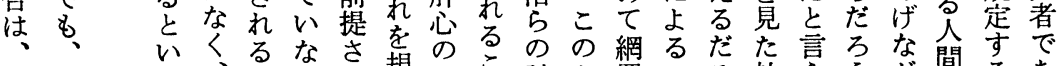

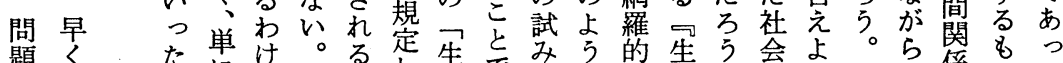

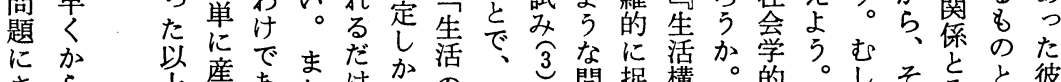

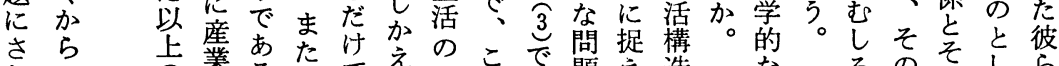

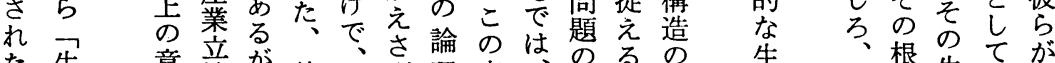

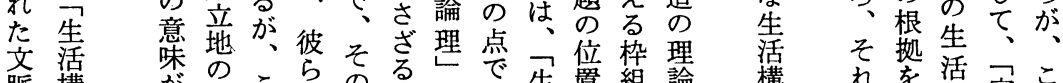

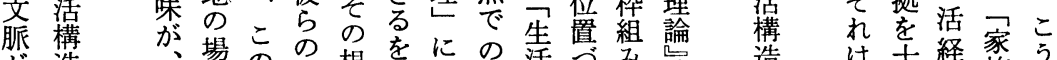

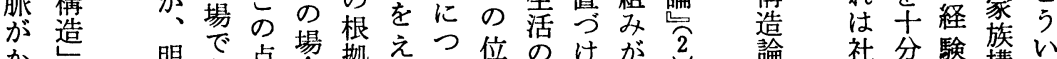

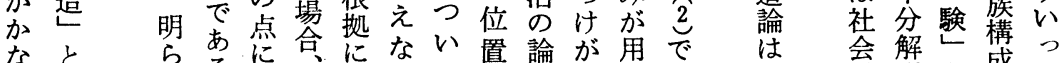
なと らいるに只にない置論が用で圽意は、会解と成た

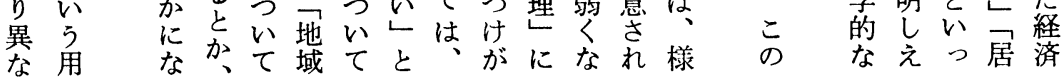

存様生こすは律対いは的 る 生指時の狌なにす右生 活 標間よら活側独なに溝 拡无やうで構面立わ述告 充表空にあ造をしちら゙造 行せ間生る。論さた、たの 動る の活。のし側そ理概 集考造造告をは念 団え学安活示人らは 参室 ご

与お計くの造。のごこ

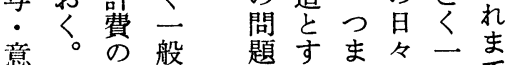
意今支船的題すすする般で の回出に起の、生的様 四行構規にで諸活に冬 つつ造定対あ個に次に

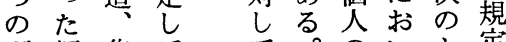
項標集てて。のいよ定 自隻団お 社こ生でうさ わ調多て 学よ品経規て た查構、的 5 経済定き

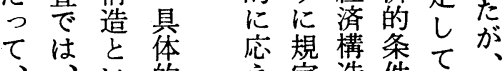
全関っ的交定造件おこ

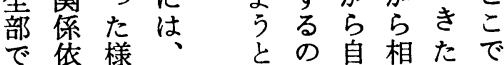

ら垷本社見そ学疑ゔ。でっ 代稿会しれ関わなとこい 都でのえで連れてこのた 方衤は再なは过て地ろよ 法社、編い、、、域が 50

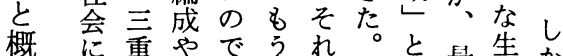
念お重やでられ珼ほ事の最活か け松ミろ代ど毫関近染し る阪之5 の明連は戛都 地市三方都確布で、律帛 域事ィだ地さら生都を社 例形と域れの活市問学 の研成しでて研の社題や 意究多たは心究息会に農 味に望ら、、なで律学し辱 をむめ方生いも性のて社

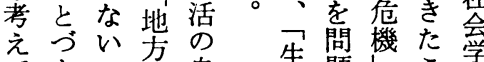
てきこの自活題炛こ学 み、と時律活にととが た住に代性論するいは地 と氐な䇭るは支理るっ視た言域

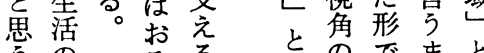

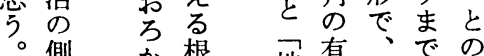
側面根地有 效こずす 関 か地は域性のな連 


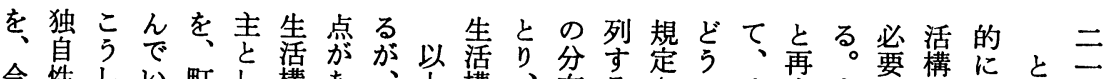

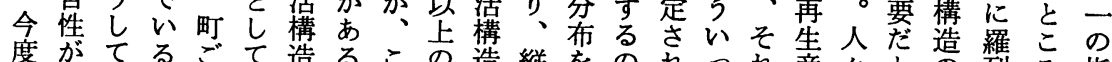

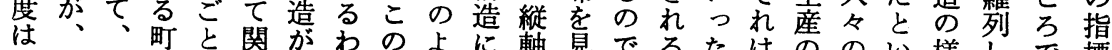

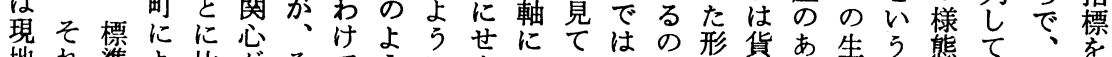

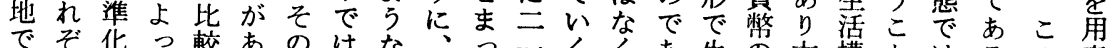
の㧈調て俥ある居なな程てのくくあ生の方構とはるの意

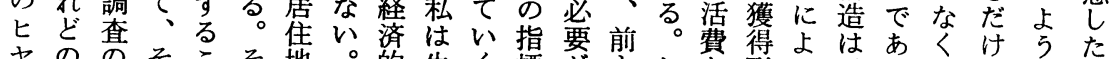

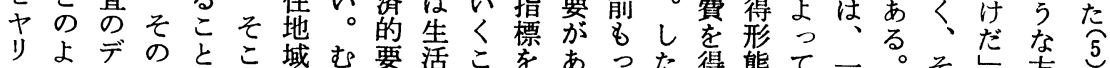

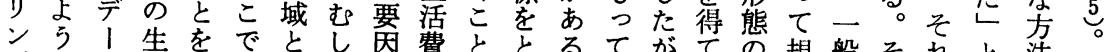
グな夕活重、穴々恩費ととるてがての規般それと法

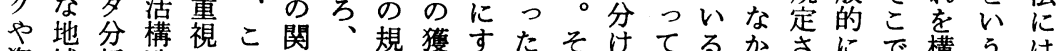

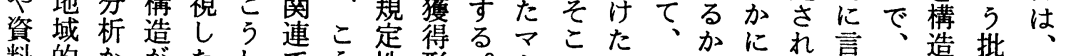

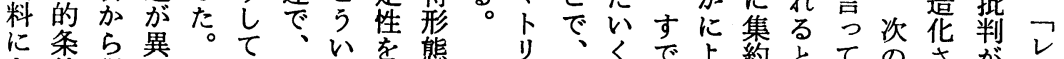

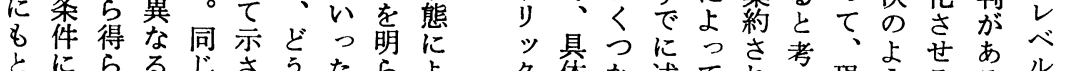

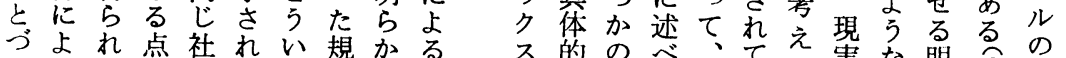

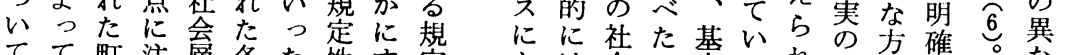
てて町注層各た性す定よは会三本るれ生法な。な

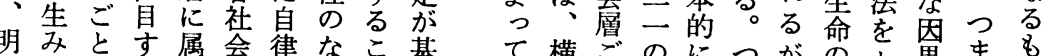

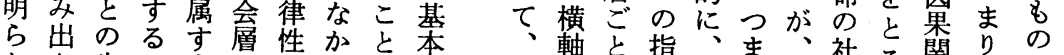

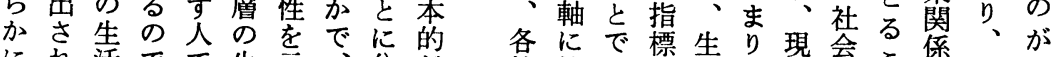

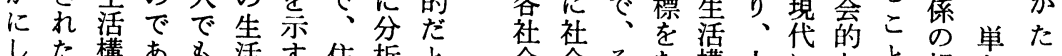
した構あも甜す住析と会会そた構人になと規なだ よの造る、構加民の考畨層机だ造々お生に管る平

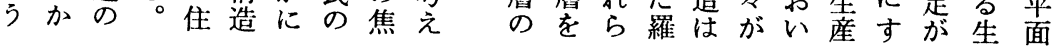

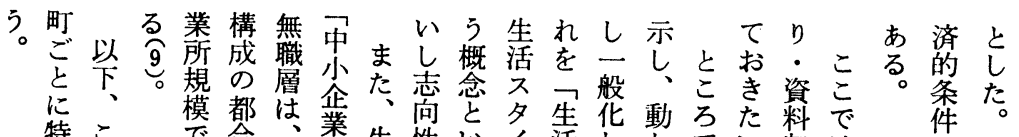

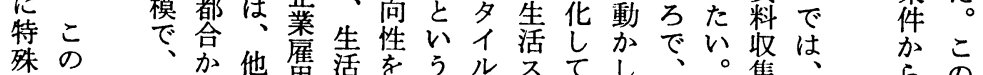
な五自ら他俑滍をこル多てじ、。集、 らの

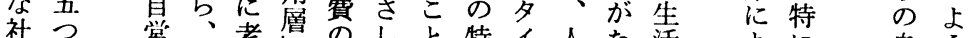

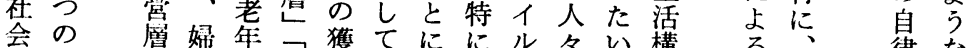
層社は人層自得、名外各い構る、律な

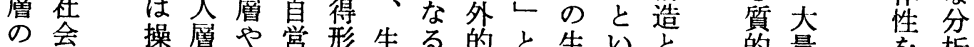

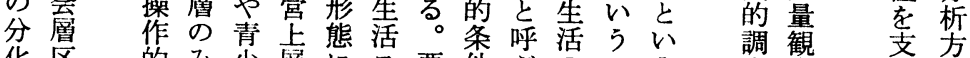

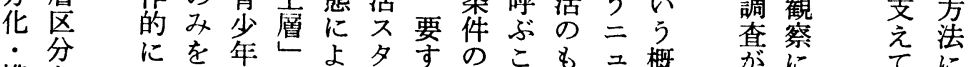

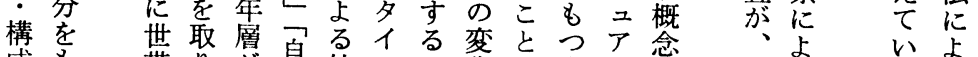

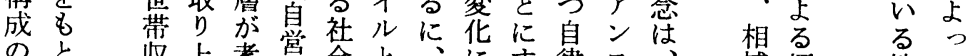

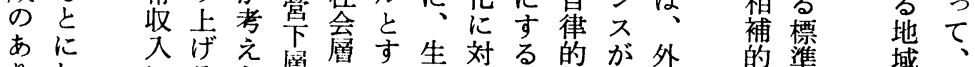

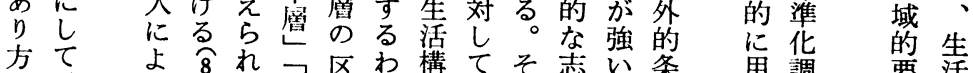

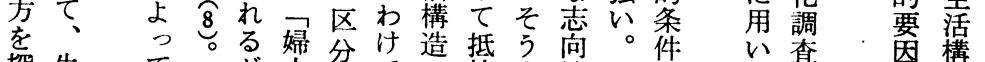

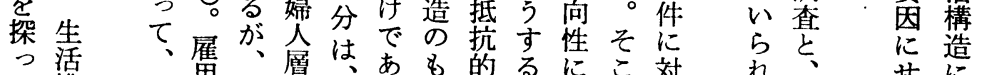

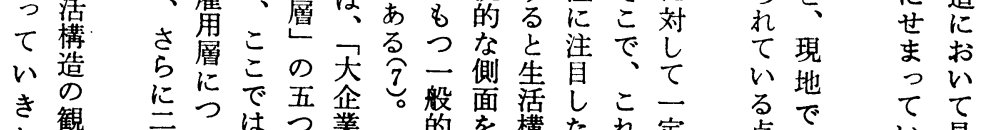

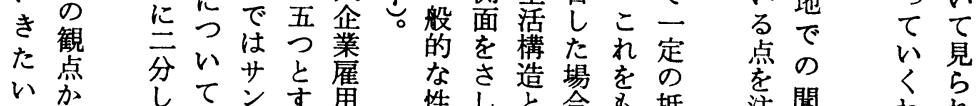

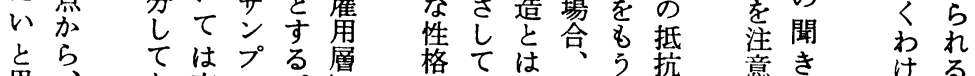

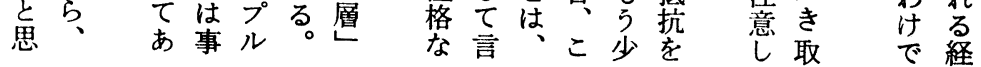


表 1 人口の推移

\begin{tabular}{c|c|cc|c|c|c}
\hline & 中 町 & 新 座 & 町 & 内五曲町 & 桜 町 & 松阪市 \\
\hline 昭和 10 年 & $1,525 人$ & (13年) & 1,023 人 & & & 35,661 人 \\
25 年 & 1,804 & (23年) & 907 & & & 48,743 \\
35 年 & 1,506 & & 821 & $332 人$ & & 98,441 \\
40 年 & 1,331 & & 760 & 690 & & 99,814 \\
45 年 & 1,127 & & 652 & 1,020 & & 102,138 \\
50 年 & 989 & & 564 & 955 & $1,104 人$ & 108,893 \\
55 年 & 837 & & 460 & 946 & 1,682 & 113,481
\end{tabular}

（注） 1. 昭和 35 年前は内五曲町は, 独立に統計されていない。

2. 桜町は昭和 46 年県住宅供給公社の一戸建分祽団地として開発された。

*『松阪市統計畫』より作成。

表 2 松阪市の産業別人口㩐成の推移

\begin{tabular}{|c|c|c|c|c|c|c|}
\hline & 昭和30年 & 35 & 40 & 45 & 50 & 55 \\
\hline 第1次産業 & $\begin{array}{c}17199 人 \\
(41.5 \%)\end{array}$ & $\begin{array}{c}18591 \\
(39.2)\end{array}$ & $\begin{array}{c}15929 \\
(32.4)\end{array}$ & $\begin{array}{c}14043 \\
(26.7)\end{array}$ & $\begin{array}{c}8365 \\
(16.1)\end{array}$ & $\begin{array}{c}6570 \\
(12.0)\end{array}$ \\
\hline 第2次産悉 & $\begin{array}{c}8253 \\
(11.9)\end{array}$ & $\begin{array}{c}10690 \\
(22.5)\end{array}$ & $\begin{array}{c}11953 \\
(24.3)\end{array}$ & $\begin{array}{c}14587 \\
(27.8)\end{array}$ & $\begin{array}{c}16788 \\
(32.2)\end{array}$ & $\begin{array}{c}18193 \\
(33.2)\end{array}$ \\
\hline 第3次産業 & $\begin{array}{c}16034 \\
(38.6)\end{array}$ & $\begin{array}{c}18160 \\
(38.3)\end{array}$ & $\begin{array}{c}21273 \\
(43.3)\end{array}$ & $\begin{array}{c}23897 \\
(45.5)\end{array}$ & $\begin{array}{c}26952 \\
(51.7)\end{array}$ & $\begin{array}{c}29970 \\
(54.8)\end{array}$ \\
\hline
\end{tabular}

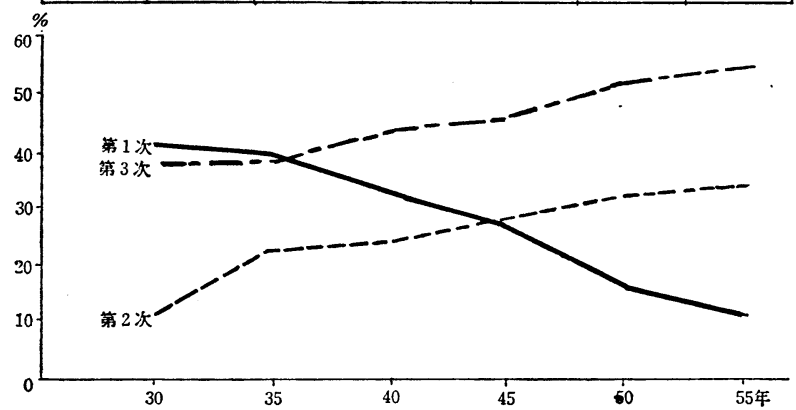

・松阪市統計春」より作成

図 1 従業者規模別構成比 (昭和57年)

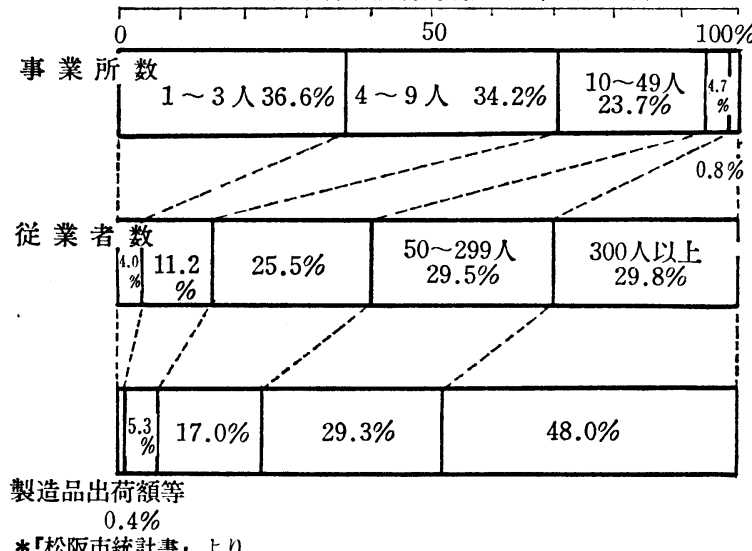

*「松阪市統計書」より

る。調 準

戦 查調 查

後 の查は、 調

人象虫三査

口之心重対

のなに目象

推 つ、松 地

移た前阪の

松 後市 概

表阪数四要

1回つ

は、にの

、典わ町

周型たを

辺的る 対

町な現象

村伝地に

の統 調

合型查昭

併のに和

地よ五

昭方っ八

和消 $\tau$ 年

三費行二

年都っ 三

!で 10 の

三あ

心らどに二村

的第のあ年

な担次誘る

以産に産村年

手業成業

はの功構に二

、比し成よ村

旧率、はる る

市洼農高以二

街高林高外七

のい漁度に年

古伝業成さ

く統の長し一

か的衰期た村

らな退にる

の商とセ変二

中業 エ 動九

小都業卜は年

小郎の今な

ので進ルい七

商あ展硝が村

店る架子一、

自表著貫

嫦表い京し年

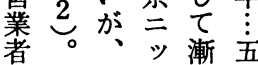

でそ古ケ増村

あのくル傾

る中かな向三

$38(1 \cdot 45) 45$ 社会学評論 
表 320 藏以上人口の權成比（55 年）

単位: \%

\begin{tabular}{|c|c|c|c|c|c|c|}
\hline & 中 町 & 新 座 町 & 内五曲町 & 桜 & 松 & 阪 市 \\
\hline 20 歳代 & 14.5 & 17.3 & 22.1 & 26.0 & & 21.9 \\
\hline 30 歳代 & 18.3 & 16.3 & 23.4 & 42.6 & & 21.2 \\
\hline 40 歳代 & 25.0 & 19.7 & 24.5 & 18.2 & & 21.5 \\
\hline 50 歳代 & 12.4 & 16.1 & 14.7 & 8.0 & & 14.4 \\
\hline 60 歳以上 & 29.9 & 30.5 & 15.3 & 5.2 & & 20.9 \\
\hline
\end{tabular}

*『松阪市統計書』より作成

表 4 従業上の地位別就業者数（55 年）

\begin{tabular}{|c|c|c|c|c|c|}
\hline & & & & & 単位 : 人 (\%) \\
\hline & 町 & 新 座 町 & 内五曲町 & 桜 & 松 阪 市 \\
\hline $\begin{array}{l}15 \text { 歳以上 } \\
\text { 就羓者総数 }\end{array}$ & $500(100.0)$ & $236(100.0)$ & $429(100.0)$ & $701(\mathrm{I} 00,0)$ & $54,733(100,0)$ \\
\hline 雇 用 者 & $226(45.2)$ & 141 ( 59.7) & $320(74.6)$ & $617(88.0)$ & $37,267(68.1)$ \\
\hline 自営業主 & $126(25.2)$ & $53(22.5)$ & $70(16.3)$ & $57(8.1)$ & $10,593(19.4)$ \\
\hline 家族従業者 & $148(29.6)$ & $42(17.8)$ & $39(9.1)$ & $27(3.9)$ & $6,861(12.5)$ \\
\hline
\end{tabular}

*『松阪市統計畵』より作成

表 5 町別居住年数

単位：人 (\%)

\begin{tabular}{|c|c|c|c|c|}
\hline & 中 & 新 座 町 & 内五曲町 & 桜 \\
\hline 1 年末満 & $0(0.0)$ & $0(0.0)$ & $1(2.0)$ & $0(0.0)$ \\
\hline 1 2 年末満 & $0(0.0)$ & $1(2.6)$ & $0(0.0)$ & $6(6.4)$ \\
\hline 2 5 年未満 & $3(5.1)$ & $1(2.6)$ & $4(8.2)$ & $10(10.6)$ \\
\hline $5 \sim 10$ 年末満 & $1(1.7)$ & $5(12.8)$ & $5(10.2)$ & $51(54.3)$ \\
\hline 10 20 年末満 & $12(20.3)$ & $4(10.3)$ & $23(46.9)$ & $27(28.7)$ \\
\hline 20 30 年末満 & $8(13.6)$ & $6(15.4)$ & $6(12.2)$ & $0(0.0)$ \\
\hline 30 年以上 & $21(35.6)$ & $15(38.5)$ & $3(6.1)$ & $0(0.0)$ \\
\hline 生まれてからずっと & $14(23.7)$ & 7 (17.9) & $7(14.3)$ & $0(0.0)$ \\
\hline 合 & 59 & 39 & 49 & 94 \\
\hline
\end{tabular}

$*$ 調查結果より作成

$38(1 \cdot 46) 46$ 
る。程以し譲加市人 お上い宅たい比町多比\&古て町。こにっ香現 いかる。゙゚わ較がく率居は、新調うま数在

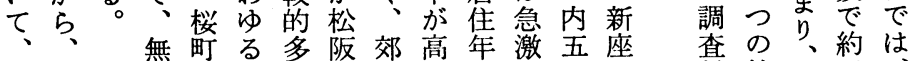
そ調計は都くの外く数に曲町詨社等、 れ查画:市居古は、減町が、象會板割全

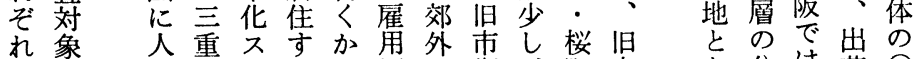
特地口県プるら層に街、町市な分は荷 徴とのの口都のがはで郊は街っ化伝額・ 的な移住 1 心中中若高外、にたが統で八 なっ人宅ルの心信くの郊位 四見的は\% 位たし供地古商で人、人外置つらな半を 置四た給区以店あが郊口の守のれ自分占 をつ内公で住街る多外は新る町る営近め 占の五社、宅でっいで急興い、はの層くる

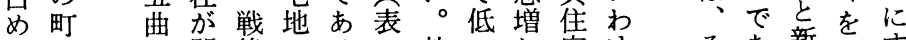
るは町開後でる 3 就いし宅ゆ そあ新占す

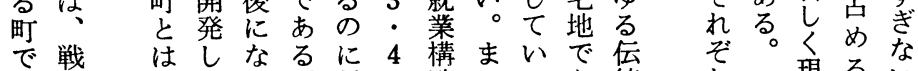
で戦は岕ななるに

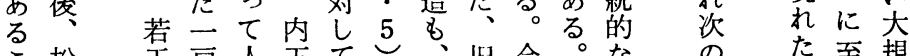

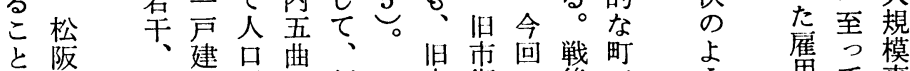

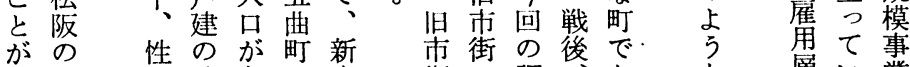
理都格建急は座街で調市な層い業

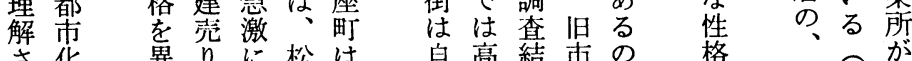

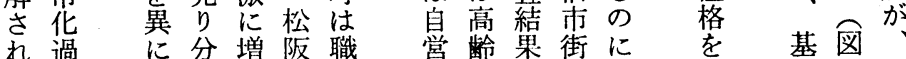

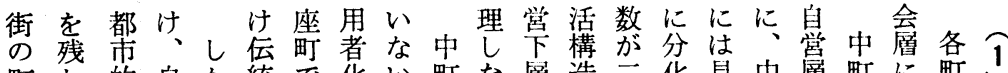
町し的自加統で华い町な層造三化見中層町に町さ でてな営し性は点でお方のとしら町がの分の はい性上、の雇へがはし点少てれと上部け生中妿社

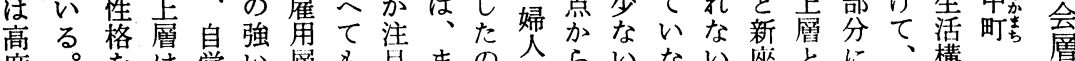

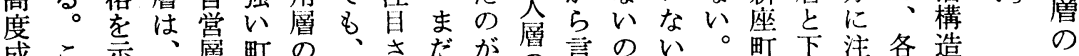

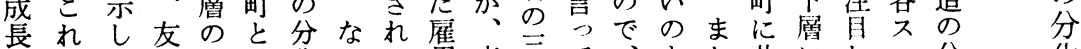
期はて人内言化おる角表志て、もた共にしコ分化

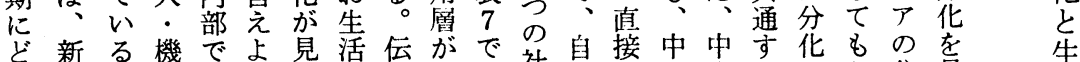

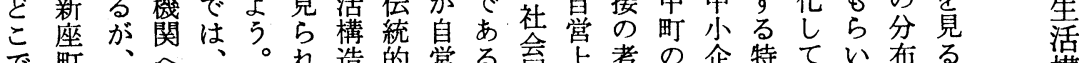

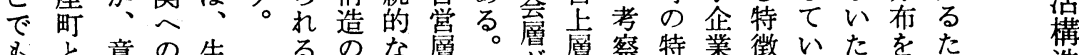

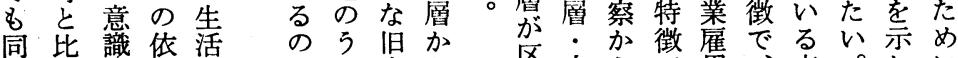
じ心面存構でえ市ら別中占で俑、点。しに

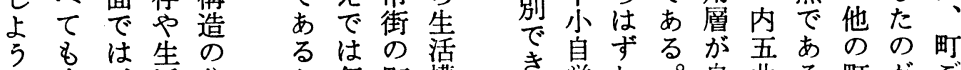
に中等分伀町構掌し。自曲る町がご

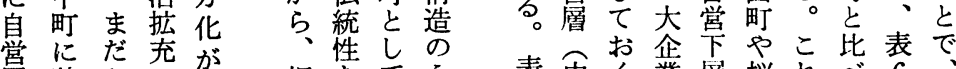

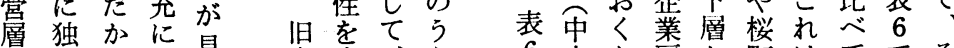
の自なお見市失、え 分のりいら街戦でを企角らと特あれ 化性伝てれでて後分業中層、い後徵るぞ を格統、る るい化町雇町はあたで的。れ 見で的比。な若しき用でサま新見な 吾

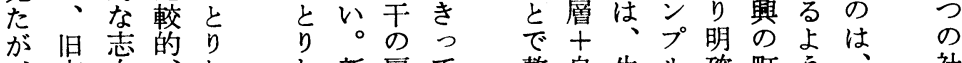
市高稺雇て 整自生儿確町 万、社 


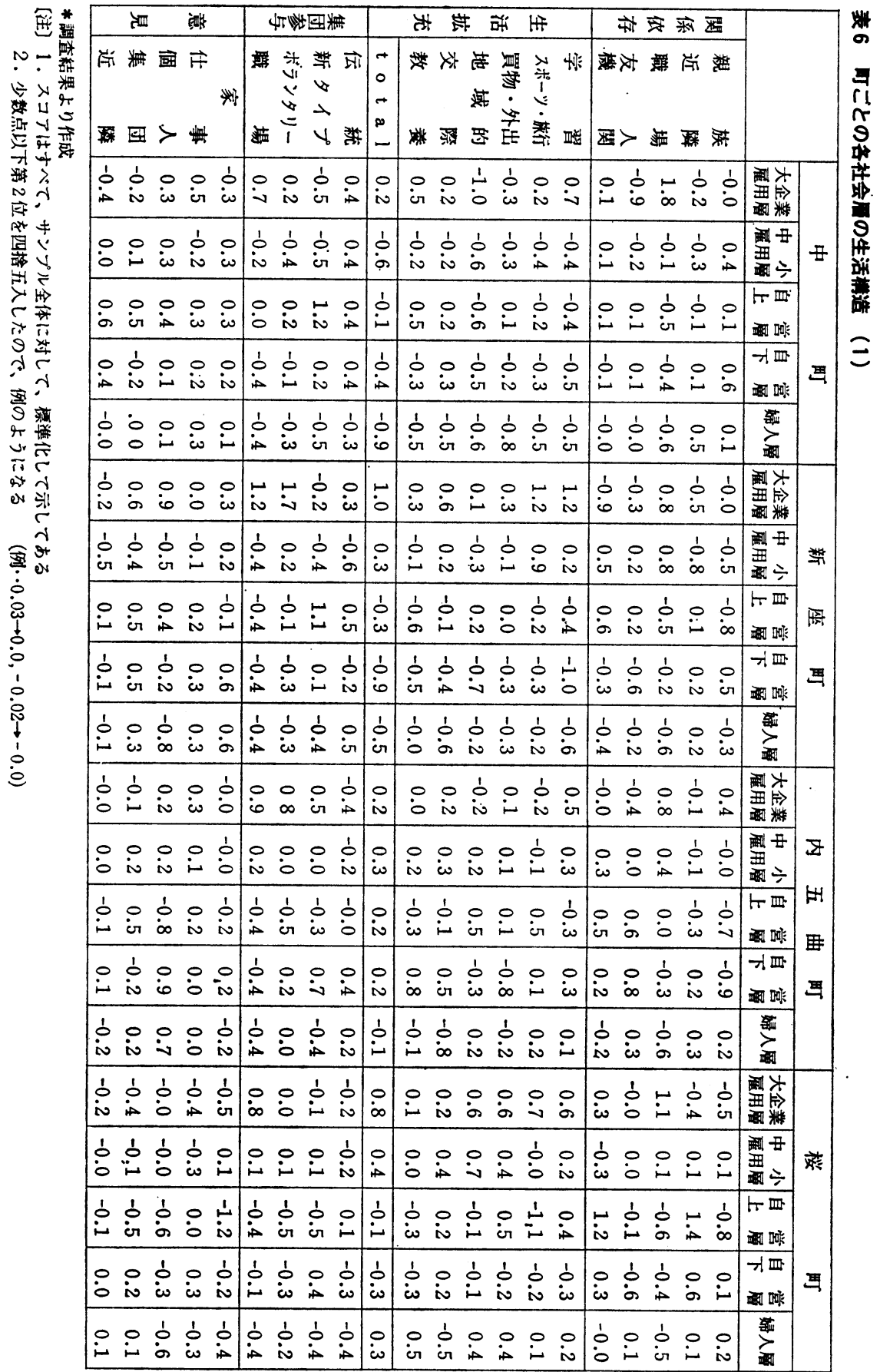




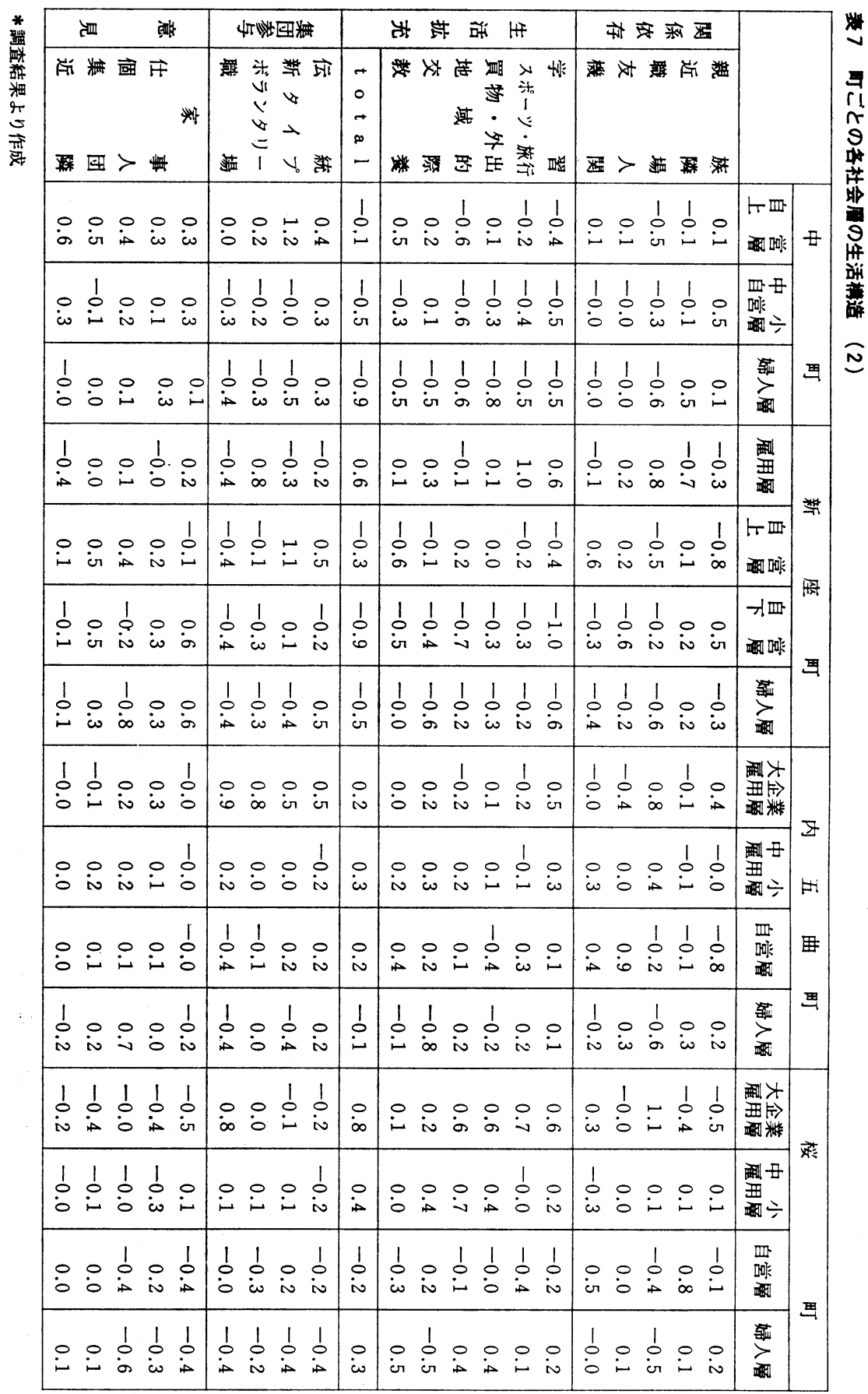




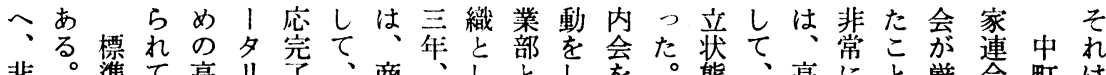

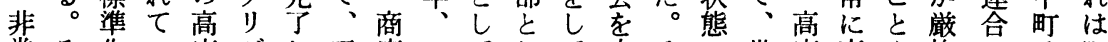
常そ化い度ゼし、正店そてして中そに世度高や格のは町 にれ調く化イ、武街れ、てい心こあ代成いなな町、ご

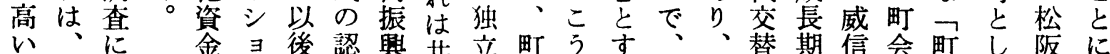

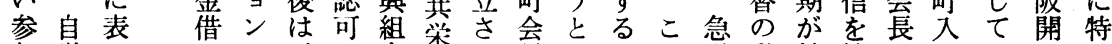
与営れりに、合会せ長い旧の激動始持とりの隹殊 を上た受適こ受法とよのう体よにきまっ言し性のな 示層自け恕のけにしう下䤞制う変がるてえの格頃形 しが営、す振るもてとに運かな化出昭いば儀がか態 て、上る興にと、いあがら長す和た、武強らを い同廨いた組至う分う心出脱老るく至こ昔に加のと

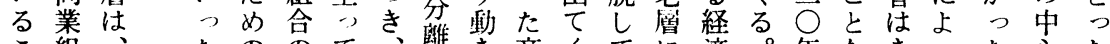
こ組、ののて、㺟き商くてに済。年なきった心た と合车積駐手い松独上業る、属䔸当代どまてら商よ

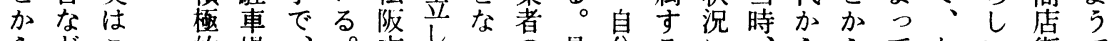

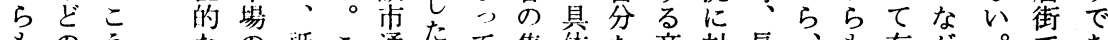

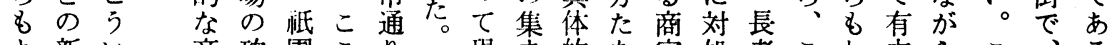
よ新い商確園こり、現ま的ち家処老こわ力らこする。 くしっ苫保祭に中されりにだのし層のか商くの 戦

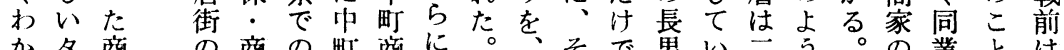
か夕商の商の町商に、。そで男い三う。の業とは るイ店共店夜の店蟲れ自層く派なし長者はま プ街同街舍世街昭し自は间の力に長か老を、だ ま地指業代開饺興四、商内商加持加支、掏町統 り域導唯化催替組一昭后会店らたれ配中としの的 、集層進の!は合作和街会街尔てに町めて町な 中団でめたモ—とに至絹商活町か対対で、き内商

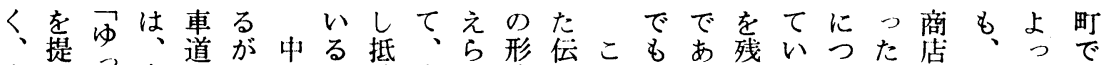
步示く墑の、町。抗企れ成統こなるしるけ街彼ては 道しり点搪はで性体た意でいるななのるつたらら、、 のた步街幅じは皇社生促識注。振がでうましをそ先 拡。步ををめ亦会活しが目 幅そいた再行現し意た、す をしてだ開政在えべ識こあべ 行て見通発側、化はるき 政、見り事が商いの、で社は 側いて、過業㸃る支商あ会 にろ買ぎの松街す配覘る腐中

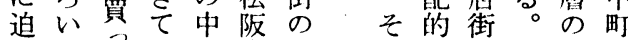
万ろても心市再机なとま生と たなてらに全開は仳いた活い

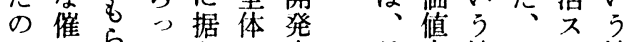

でしらてえの事具志地こタ地 あがえ\&充流業体宂域 5 イ域 るでる商困き動が的に的いル社

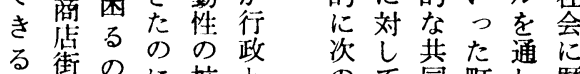
上街のに搪と筒町し歴 うとで対大间占も梨のて史 にいらっていでな定に花新に 車 新て振 観 険 道しむ興点さ でいし組かれ は理ろ、合ら、て 事 の \& シ し 保 例自 裏 $、$ 持 に律付テ地さ 表性けム域れ れならに組て な念、で、い てい机支織き

興らあえりとしの帒 組、るで、いて ま か 合他。、中う世地 が方そむ町伝代近事 、でのしで統交代業 そはたろは比ぬ替的竟 以較、の伝プ と自け つ的中伝統 亏駆営継 た活町統的イり層心 活発の的なド立へだ 動な息な都かて と 長 組活営観市らた照男 織搪層が爱る他のしで、

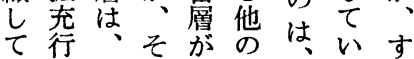
い動一の新町 ᄀつみ るを方際しと中たや こ展でのいの町のか と開伝起生対はでな はし統動活抗松あ世 、的妿構意阪る。代 うる観なをで中し替 まの念つ身あ心かに 
つ一伝ル存て化伝つ座業方で

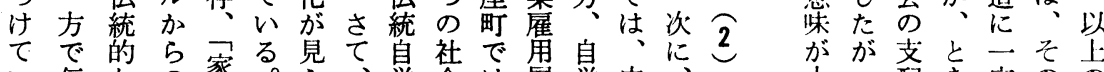

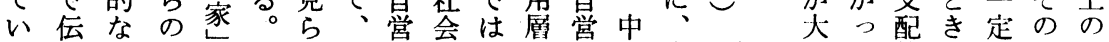
る統中脱やすれ中層層、と層町表新公きて的との町上 の的町却やなる町かが表中内と 6 坐满い、なし自に

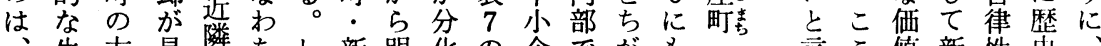
生方見隣ちし新明花の企でがも 部性史

す活がら対、か座確しよ業はつどは壳しを的中

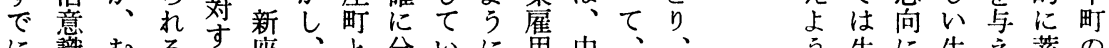

に識むるする座、と分いに角中、、、生に生え蓄の

述をし。る町中心化る、層町雇新

今残々と志の町っしと雇を同角座

たし積こ性䁘新旧点え存層便様層町

こが的がと営座市点方曾便上自部

ろらな机膚町街、自上層営分

かも、の生たは、告町特る営雇卡厤に注

理他あ拡点中はで的中盧角層ら日

解方る。充で町法で町: 層の明し

でで。行伝とそ市と自と分確て

き二中動伝比のいる営し化にも

る定町に統些形ず。が卡てが分ら

とののつ的て態れつ層二見化い

思都自いな、㤎\& て括らした

吊営て生親若息、婦すれてい。

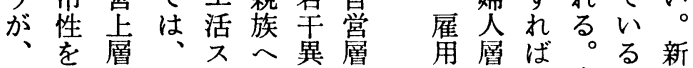

そ身がょタの学算の

活 対活る積よ

構しスこさう

造て、夕

自一ルあきい

律定やきた歴

性 の地 5 文必

孝抵域か化を

え性織なる

るをのうテち、

う示形た㕕

ぞう成をが、圭

でう党そ住着

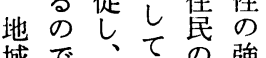

域であ全、生強

もる体そ活町

れに、りイ依つ分范四新企他町

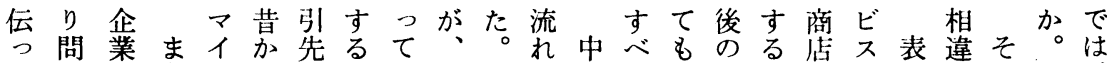

て、題とたナらや適はむその町き、高町街業 8 に

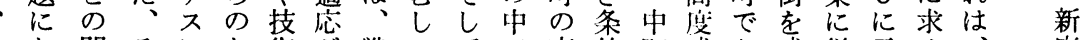

地な関そにな術が戦ろてで商件町成あ成從示め、座

区ら係ら働じを問後プ、、人がの長るし事さら新町

組なのいいみ取題ラそ商た異自期。て专れれ坐の

織い方っただりで松スこ店ちな営にしいるてる町满

は。がただと入あ阪にで街につ層新たる人いると合

非し重職ろかれつ市作はととてっしがののるる中

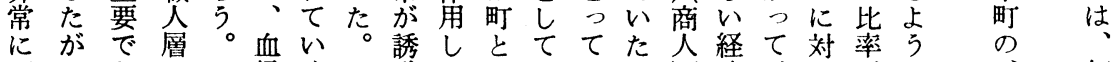

弱つあに縁くし致たじのはの乞済、対がに何

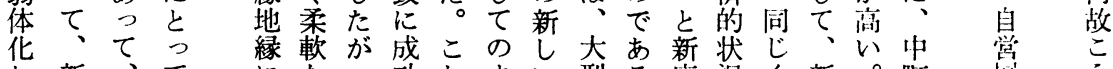

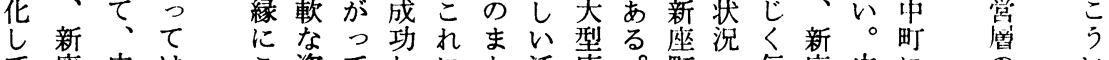

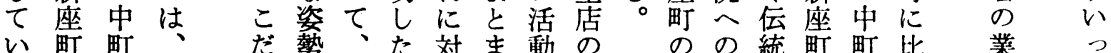

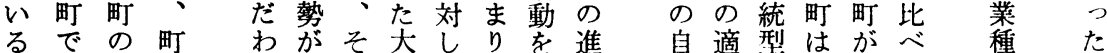

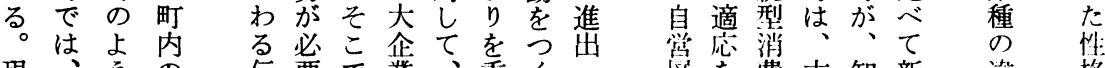

現、うの伝要で業、重く淛層を費古卸新違格

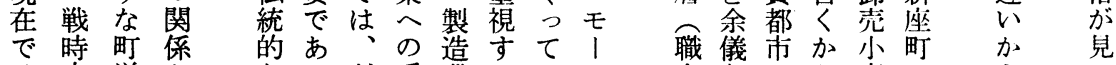

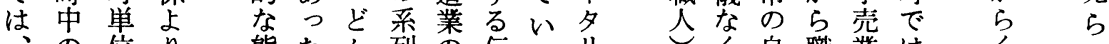

の位り熊た岕列の伝くリ步く息職業は

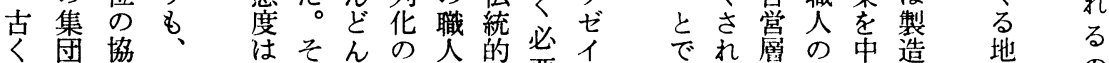

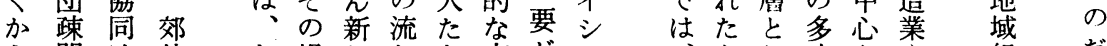

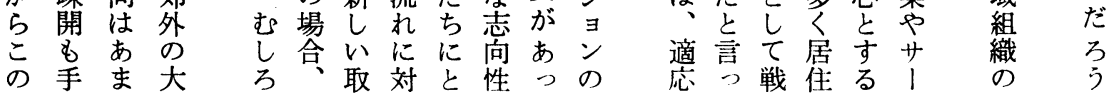


表 8 産業別就業者数：新座町之中町（昭和 55 年）

\begin{tabular}{|c|c|c|c|c|c|c|c|c|}
\hline & 建 設 業 & 製造業 & $\begin{array}{l}\text { 卸 売 } \\
\text { 小売 }\end{array}$ & 金融 & 不動産業 & 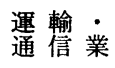 & $\begin{array}{c}\text { サービス } \\
\text { 業 }\end{array}$ & 公 務 \\
\hline 中 町 & $\begin{array}{c}16 \text { 人 } \\
(3.2 \%)\end{array}$ & $\begin{array}{c}58 \\
(11.6)\end{array}$ & $\begin{array}{c}291 \\
(58.2)\end{array}$ & $\begin{array}{c}8 \\
(1.6)\end{array}$ & $\begin{array}{c}3 \\
(0.6)\end{array}$ & $\begin{array}{c}17 \\
(3.4)\end{array}$ & $\begin{array}{c}100 \\
(20.0)\end{array}$ & $\begin{array}{c}7 \\
(1.4)\end{array}$ \\
\hline 新座町 & $\begin{array}{c}7 \\
(3.0)\end{array}$ & $\begin{array}{r}44 \\
(18.6)\end{array}$ & $\begin{array}{c}91 \\
(38.6)\end{array}$ & $\begin{array}{c}6 \\
(3.8)\end{array}$ & $\begin{array}{c}1 \\
(0.4)\end{array}$ & $\begin{array}{c}12 \\
(5.1)\end{array}$ & $\begin{array}{c}67 \\
(28.4)\end{array}$ & $\begin{array}{r}4 \\
(1.7)\end{array}$ \\
\hline
\end{tabular}

表 9 姆人两の生活拡充行動

*『松阪市統計書』より作成

\begin{tabular}{|c|c|c|c|c|c|}
\hline & & 中 町 & 新座町 & $\begin{array}{l}\text { 内 五 } \\
\text { 曲 町 }\end{array}$ & 桜 町 \\
\hline \multirow{4}{*}{ 们 } & 20 & 0.0 & 11.0 & - & 16.3 \\
\hline & 30 & 8.0 & 9.7 & 14.5 & 13.8 \\
\hline & 40 & 8.0 & 10.0 & 22.0 & 10.6 \\
\hline & 50 & 9.8 & 8.3 & 8.0 & 10.7 \\
\hline \multirow{2}{*}{ 令 } & 60 & 4.7 & 6.0 & 11.5 & 9.0 \\
\hline & 70 & 4.0 & 11.5 & 4.7 & - \\
\hline \multirow{2}{*}{ 学 } & 中 & 4.8 & 7.2 & 6.0 & 12.0 \\
\hline & 高 & 8.3 & 9.2 & 14.0 & 12.1 \\
\hline \multirow{2}{*}{ 歴 } & 然 & - & 8.5 & 8.0 & 14.0 \\
\hline & 大 & - & - & 22.0 & 12.3 \\
\hline \multirow{7}{*}{$\begin{array}{l}\text { 世 } \\
\text { 帯 } \\
\text { 収 } \\
\text { 入 }\end{array}$} & 100 万末満 & - & 8.0 & - & - \\
\hline & $100 \sim 299$ & 7.0 & 7.2 & 6.0 & - \\
\hline & $300 \sim 399$ & 6.0 & 12.0 & 10.0 & 12.7 \\
\hline & $400 \sim 499$ & 6.5 & 10.7 & - & 15.3 \\
\hline & $500 \sim 699$ & 4.0 & - & 10.5 & 11.9 \\
\hline & $700 \sim 999$ & 10.3 & 9.0 & 14.0 & 13.7 \\
\hline & 1000 万以上 & - & 6.0 & 22.0 & - \\
\hline & 1 年末満 & - & - & - & - \\
\hline & $1 \sim 2$ & 一 & - & - & 7.0 \\
\hline 居 & $2 \sim 5$ & - & - & 14.5 & 12.3 \\
\hline 住 & $5 \sim 10$ & - & 11.0 & - & 14.4 \\
\hline 年 & $10 \sim 20$ & 6.8 & 9.7 & 12.3 & 9.5 \\
\hline \multirow[t]{3}{*}{ 数 } & $20 \sim 30$ & 6.7 & 9.5 & 8.0 & - \\
\hline & 30 年以上 & 7.6 & 8.3 & 7.0 & - \\
\hline & 生まれてから & 3.0 & 5.5 & 3.0 & - \\
\hline 平 & 均 & 6.5 & 8.9 & 10.4 & 12.6 \\
\hline
\end{tabular}

れ的さ識十てのに町 る展な面以分いよょに 。開いで上になうう居 新をのはの展いに文住 座通で伝よ開 町しあ統うしし町か 、 のてる性ななたのろ町带

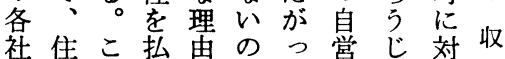
会民气拭かでて、層て方入 層のでしら、あるを町る 近萿、が新 隣 構 町 5 座 人造の\&町 のを就、の 志規 業行自 向定構動営 がす造面上 共るので層 通と相はは し心違十 てうが分中 低連、都町 小関地市 と も、組なが 、見織展つ こ ら出歴を意 る。䡠内 5 行 的 の 組 事 な 団 織 が 思 体し維 心 活七持 動いされ 契よてれ な 機亏 心 しなる 同だ た業け㬝 生団でと 活体あ 部 充存 。息 名在 中黨 


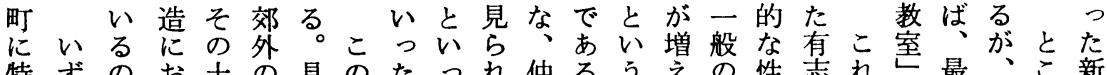
特ずのお土の具のたっれ仲るうえの性志れ是、こ新 殊れでけ着婦体よのたる間。理す住格のはな近ころ座 なにある性人的 歴せる伝に層ななあ縁さちまで、で、町节新い新 史よ。統よとデ地る者らでり、ひあカ、の、座っ新地 的性るは1域。㤎にま、会とるラ非公ク町た座域

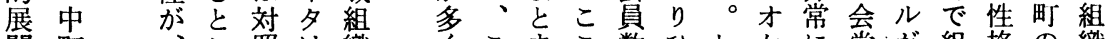
開町、こ照は織くこまこ数ひしケに堂が組格の織 のや召乃的後の 見のりでをとかの興にあ織も婦の 結新 学がにに伝ら拡、は制りも指味力るさ町人あ 果座 ラ大示統れ大事、限に、導梁ラ。れの層り と町方き伝す的る過質中す十こをいオを婦は方 と攵い統がな程的町る分のし特ケ婦人非と

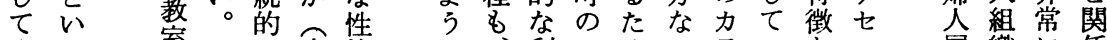
生っ室そな表格に、利つめレラいをッ層織に係 したなし生 9 は会恝町にッオるもトなの伝し

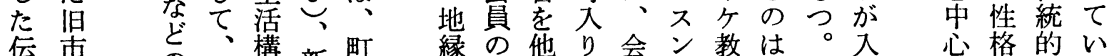
伝市 の 、構新町緣の他り会之教は、入入格的い

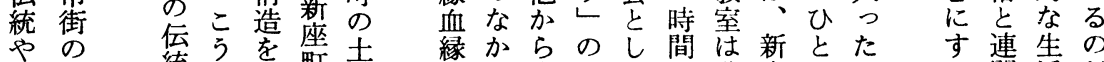
地町統い保町着をに守儀てを非座つのるる関活だ 域に的っ持中性た親乃式の確常町はを団し構ろ 組お性たし市と町と等うを組保にで、き体て造う 織い售て町関っ・と思織で好自そっにいを

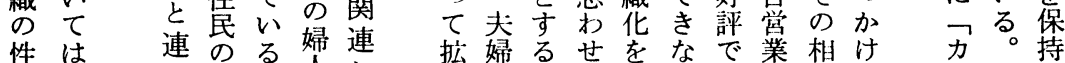

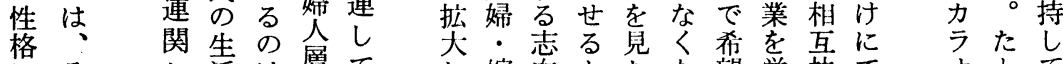

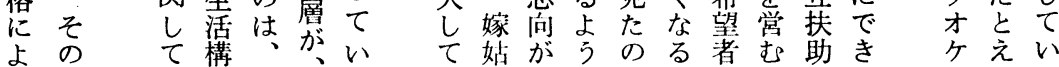

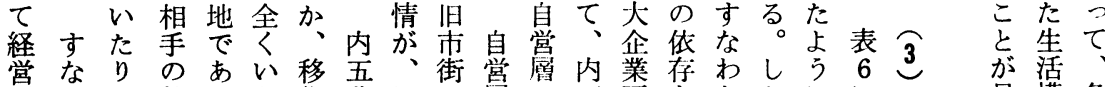
形わし 飲るな住曲旧の層・五雇をちかにに見構各 態ちた食かい後町市町に婦曲角高、も边出造社 心、者店らわにの街と分人町層め郊、内ど五产さと会 転旧でを、け雇場の対化穈でと、外こ五り、曲恋机の噟 換市あ出ほで角合町照がのは積のこ曲、町恙た関の に街るしとは層文的見四、小極町で町今 うの。たんなかほ異でらつ表企的ではに度 ま町りどいらとなあれの7 業なは自なは くで、が転んっるな社の雇生、営る内 成は人自、じどて。い会よ用活自尿と五 功口営もたのいこの層う層搪営に曹 し古增層と者自るのはがにの充下上自町

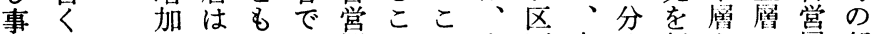

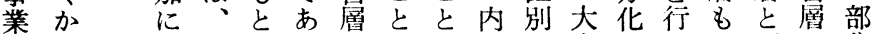
をら近がるは学は五さ企がつ上下よ分 拡のも鉄農。、関、曲れ業はて層層りに 大自な道家古高連郊町る雇ついとのも注 し営い路がく度し外と。用きる同分雇目

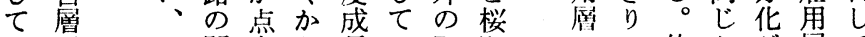

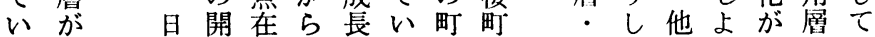
つ高用通しの期るのの它て方う見がみ た度品後て土に。自共小くによ

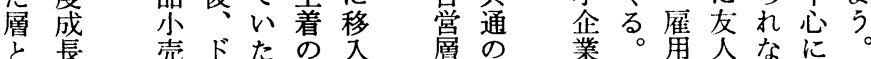

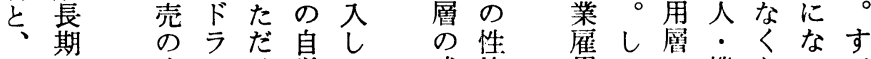
そを占イけ営て 成格角たで機なっで

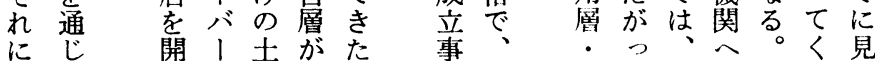
連 生 地 造 域 が 組 あ 織 る の 程 伝 度 統 規 的定 性さ 格れ がた 維 り 持 さ逆 れに る 々 oW たっ 

も市理にるる 古生関しいにないてに年収 9 は

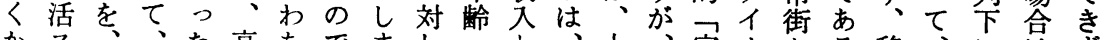

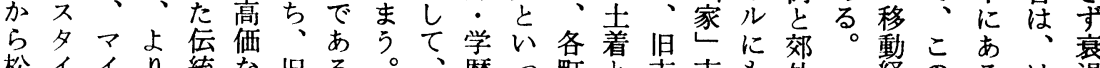

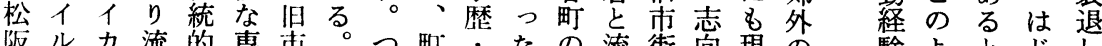
阪ル力流的専书。つ町・たの流街向現の にを। 動な門 街 居すを性生サの 住で利の活 | 婦 しに用高構 ビ人 て身しい造 いになが郊を壱が 伝けら、の礼た 統て、婦のる

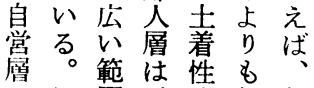
の旧每出都え相新 身街選市に扶町 での択に、助の 婦的多維的力 戦人にく持なラ 後膺活あし組才

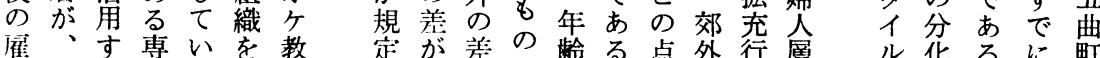
ま居収基婦動よとれ町 り住入本人と次て 験よ とじし

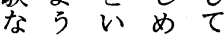
、年を属層い\&っい相要なっかい 基数コ性にっ、たる違手興新新た 本をンとつた都項。は伝の興し層 属コ卜町い地市自具、っ自のいと 性: 只居て域的に体自て営自経に よ卜 I住、移なお的営、層営営分 り口ル年生動性いに層全の業方化

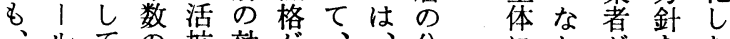

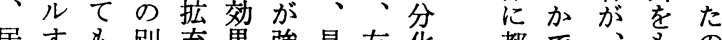
居す母别充果強見友华都で、もの 住る、ご行がいら全だ市はほつに 年之旧と動大のれ依け的、之て 対

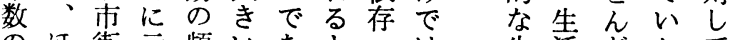
のほ街示頻いあな过は生活どたて、 ほぼとし度よる。う生な 活構なりり、内 がそ郊たを、でこ萿く婦务造のです五

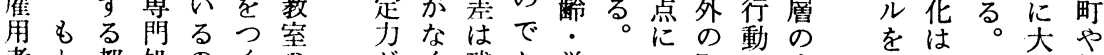
者上都処のくの只く残あ学つ町・生示見し手桜

れやのが企てみ

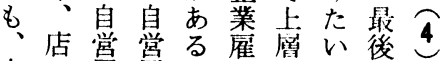

墑は層層と用と。に

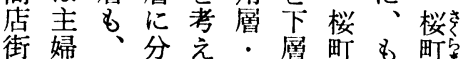
をに人化て中の\&う 形ま口がよ小分内-. 成かが見い企化五i度 しせ増らだ業が曲 十てえ机ろ焦認町表

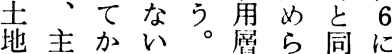
に人らの・机様も 執は白は自なにど 着勤用、賞い雇” すめ品内糜。用て

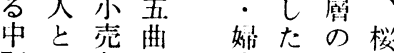
町いな町人が比町 の どと倜”摔の 伝たの同のてが生 統ケ店じ四、高活

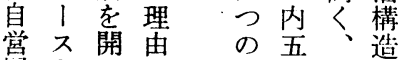
層むいに社曲自告 と多たよ会町営分 は、脱る愿と奮化 企。サ。同にを く年分じお是 異ず組町化大いて
る。させの分れ行街階新は华 郊こ阪をすなこ郊的心戦な 外亡市推でり、外な地後か 地でのしに登谁見生でに想域站で 区旧登進見生に対違生誘、 都市過てょ厉的、をさ業 心街程いう夕いな士始れ主 地のがっにイつ生着めた媂 区自、た中ルた活とる大 の営郊の町が郊不流こ企し 工層外でのモ外夕動と業て コののあよ1のイとのや現 口生婦るう夕婦ルいでそれ ジ活人。なり人をつきのて カス層こ旧ゼ層生たた関き ル夕にの市イに多地婦連た なイ新こ街シよ出域人企の

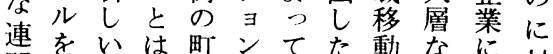
関をい生非にの町ンで動なに結対 が分活常㧤動之で\&でびし 見化スに河きしあ絡あつて 出さ夕興る伝作担る。合る。さ、郊 せ去深統りわ担外 るいをい自出れての外の のく定。嫦した 、上で婦 でと着戦盧、購旧方全人 あいさ後のそ買市な䈏 


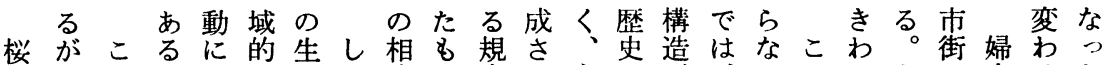
町、う。対活活加違の定れ主のが的のめとの人るた は培いし動スしがも力てと浅強そ性よてり町層と新 、っっで、全、はいしいくの格う積わとにこ興 昭てた消へイ表く考弱くて郊規士をに極け、はつろの 和き相極のル7 認えく。職外定着示、的、対いが自 四た違的参にをめに、し場のさ性し桜に桜照てな営 六地はで加興注らくそたや町れゆて町行町的もい層 年 域 以活実 降動は 炎関桜

居連町 がしの 始て 自 ま い治 つる 会 た新でが

興 あ 短

のるい

団。年 あ゙加興注らくれれが移でてえい町れら町行町的 る度媣涑なのゆつ動はいにる場て婦なす の合いくいかえて経々た。町。合い人非で玍々

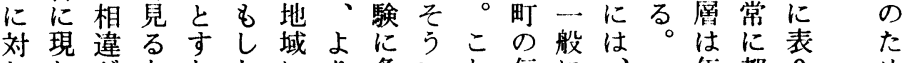
しれがなれれにり条いれ伝に、留都 9 め ててあらばな支都件っに統中ど 桜るこ学。的け地し歴町社若のし 域 町。と内う郊れなら域て史。会机高たに の内に五考外た地れ的、金新曆たいよ 対 鹤五気曲えの生域て要桜い座8 め生 5 す 用曲が町ざ町毠で、靣町 $\leadsto$ 町内、活に、 層町がとるの構は各にやたと五生不態 はで々桜を社造、自は内要い㤟活多内 度 地韭はく町え会の地のあ吾因》町拉个五字 での常こそとま層自域生ま曲にたと充ル曲他

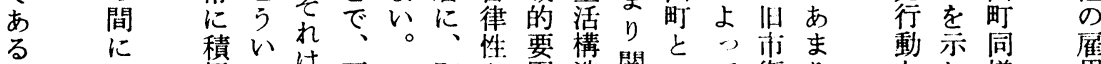

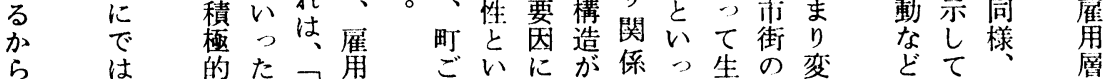

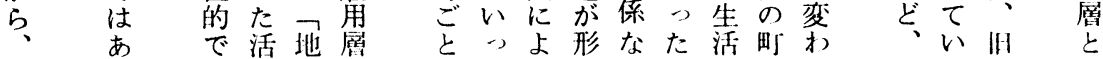

るれ、統せてごはは、。な゙企て企事やく努ま五自 し。、浅のて自し、雇、策い画と運かた力と严治 か そいもあ分た会すの用多につ・い動らとにめ作会 も、の 町つげが経長ぐよ層額勤た運う会のえよ役に結 町で\&た経験のれう中のめメ営形な祭ばっを舀成 そにもうい験だ献たな心寄るンさでどで、て買粪も うま、ひとしと身リ非の付サバれ固のあ会、つ処最 いた移といたい的１常地にラ、て定行る長多て理近 つ新入ううようなダに区よリでいさ事つがく出埸の

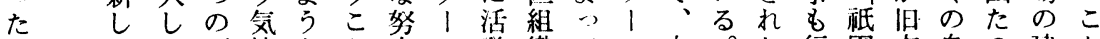
地 いて可持なと吕の発織てマ自。た行園市自の建と 域伝き能か町导でを存なで自ン営こメおさ街治が設で 行統た性ら内字あ支在地あ治で業れンれんの会、問あ 事を人をでのるえで域る会あ者らバて新活現題る

は築た考あ需。たあ活 いち劣っ囲祭のが。動

た て高たた気やが。か

单く以憶飞こ一抒子小桜

に礎声くの今どどし町

移倍介机このりを 、に

入なしると子をのこ定

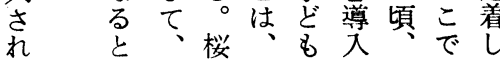

るいそ町地たし旧もえ

のうれの域ちた市興た

な゙こがよ文にもの街味第

なと活な化味町深の

でか䵇やわかでい理

あさ吏伝わつ過の间
運るがの、いが町動在が。 嘗こ人々虫。人出定自ちの しの含は心こさ身着治上組 て点ま、にれれです会が織 い、れ会、らたある長”化 る怔て長婦は。つよでてが 内家いが人、またう、か本 五なる説愿自たこにそら格 曲どが得の治、となので化 町の、し協会他かつ後あし 上少ほな力長にら、て彼るた 対地ど、とに势阪た献の

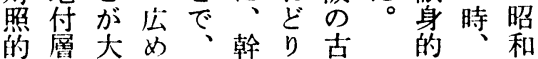




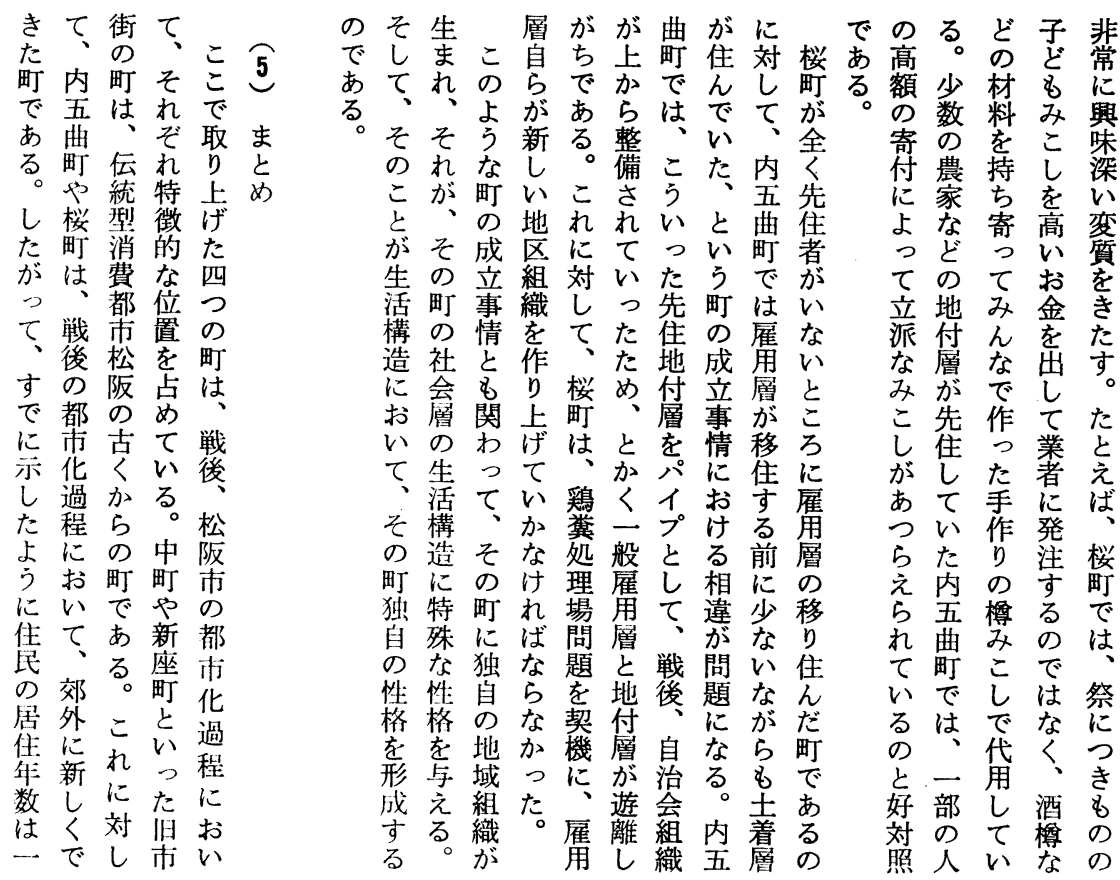

もぞし異て郊にのはるいの表お的ゆてに古のとが般 と拟合な適外異文町上を分れいなる 連く内しど で異上うつ応のな化独廨含化てて郊伝そなか部てん旧 独なかとたし婦つシ自々みがい見外統れるらに松ど市 自っら、位て人た不の分な見るらと的は若居お阪ん街 のた、っ置い層適テ条解がら。れいな生い住い市減に 適位都たにこを态么件しられしるう色梁雇すてでっお 必置市連あう主形やと衰もたか中基彩有甬るははてい 形にに関るとた態地磨退、のし町本の夕層自一そいて 態あおも町しるが域这し新で、。的強イを営般れる長 るる見のた担生的的てしあ旧新ないルぼ層的ほのく 生町て出社よい怼活ないい手出動特く状て街町华市側ど残都人対郊

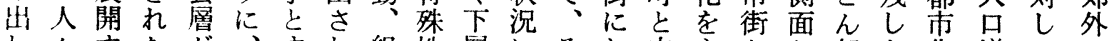
し、名たが、すれ組性層にそお内市をとか郊な化增てで

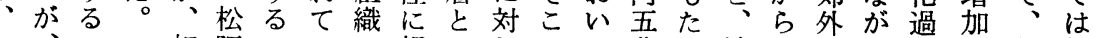
か、エ 相阪モいの規のしでて曲ら流言にら程が郊短

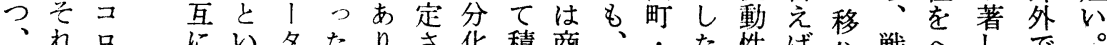

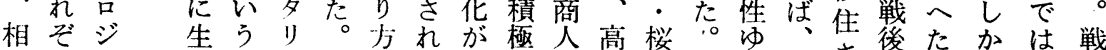

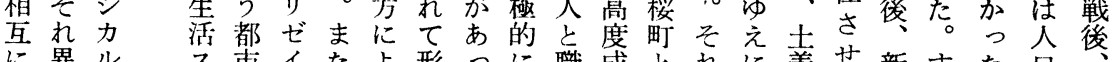
に異ル市イたよ形っに職成とれに着せ新すた口 影ななタにシ、っ成た適人長のは新性てたなおが旧

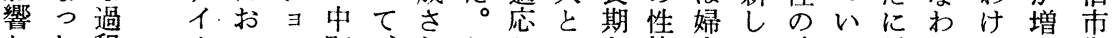
した程ルいン町、れししいを格人い強っ誘ちでえ街 合歴にをてのの各てかてう通の層いいた致、はてに 与史お通、流自社きもい職し相やわた。し都ないお

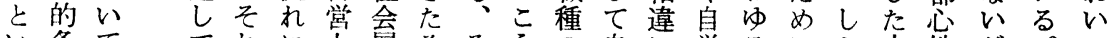
い条ててれに上層そそうの自に営るにた大地が。て

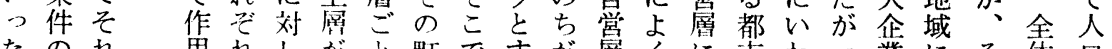
たのれ用れしが上町ですが䚤くに市わっ業にそ体口 
がだでがす初・、スそ統は代明域結し考

ろあるる咅テれ的た化ら的果たえこ最

そうるる新諸ていムをなしを的活とのて後

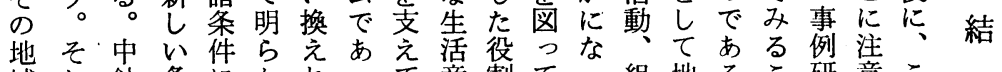

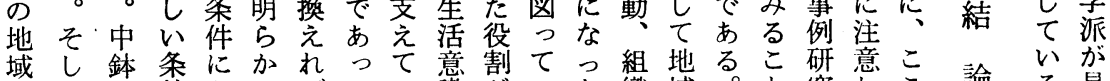

のて、正件よにばたい識がいた織域。と究しここ論るる見

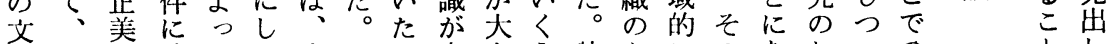

化その適てう生て の自きう特あにのあねつの

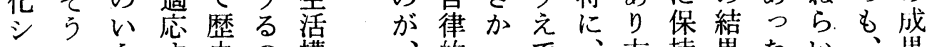

之

スいうす史の構

テっフる的で造

、的つで、方持果たい紧

中なた、中にささ传が

ムた履とにあの

町推。中町よれ住そ、午

や歴歴き形つ自

に進こ町でつて民蚱の生の統

組史効に成て律

織的果一さ、性

歴力こ町はてきたた活普型

史とでは松商、た生め構遍消

的なは松店あ個活に造的費

形自定れそは、

にっ、阪街る性構生の結都

保た自中の程的造活自論市 持の営中指度なは構律を松

な性 社自き以こ

どを会律た前の

に亡 学性生のよ

よら 的を活経う

つえな示構 済に

てる意す造的歴

集う橗との条史

合え考社件的

的で考え会をに

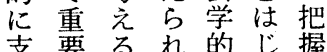

さで磻心導、文、造性導阪

がた

明よ

55

か な

に社

な 会

過

た程

とが、

れあがだ膚規化町のをいに

苾

てる分と が定 シ 独町石て限

き。化と世さ不自ご地お筀

たそすい代れテのと域きさ

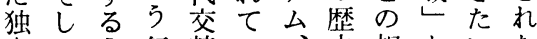

自てう伝替い、史相といた

の、え統をる るお的違の とも

文まで慧へこよ展に関偲の

えなべる側めし

化さ、識て と代開注連う。で

任

整

消

賽

者

松

防文

に

掠

らのきの面とでに伝の近が地の目で。あ

い

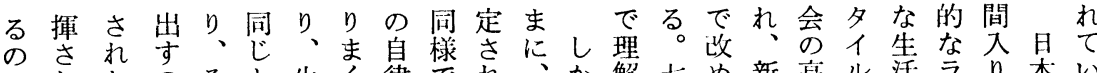
でれたのそよ生く律でれ、か解七め新高ル活ラり本い はるいでれう活様性ある単しさ な。くあをな行々はつこな机年個い市連造フ果、人 くうつる独外動な歴たとる個る代人ラル関なスた戦々

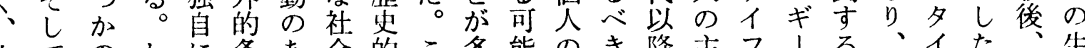
生て、のしに条あ会的こ多能のき降主フ組件りる゙消も生ルた。経活 構そ材がみに方係根でっが体あ社的夕費の活の同済意 造うをつ合対にの拠のた語性ろ会なイ型でス定時の識 全い独てせせ独歴を事よらにう学要ルの多着に高の 体っ自、るて自史名例うれつ。的因のラるイをを度働 のたに個こもの的つ研にるい 志生組人と、規な子究思汃て 向活叒ので選定編のでら。アは

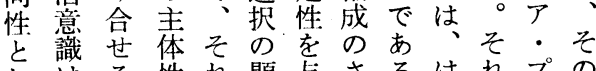
しはる性れ題与さるはれプの

て单生はぞ材え热こっは方とき根 生る意う特諸のが齐り生りが 活観識い殊諸で、示と活に明 ス念のつな個あ個さ諸構前ら 夕念働た適人る人れ個造提か くしき歴㦄にすのた合論さに ルてを史形よそ生。のにれさ と保通的態つの活個生おたれ し 持しにをて結意人活いりな てさて蓄生異果識を構て、否 なに可イ。ル兒そ成き 生対能フしとたれ長な 活し性スかいのはをの 構てがタしっで個へで 造期模イ、たあ人てあ 論待带ル最もるの、る。 のがさは近の。レ最 流かれ、ではこべも 行けて疑は、こル先 はらい問、こでに進 これる。こう問お的 こて之目のい題いな いいてををようにて㾖

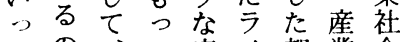
たの、て産イ都業会 文でそ見業フ市主の 歴れ発積みな脈あこら社 


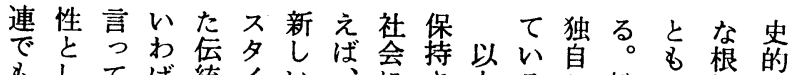

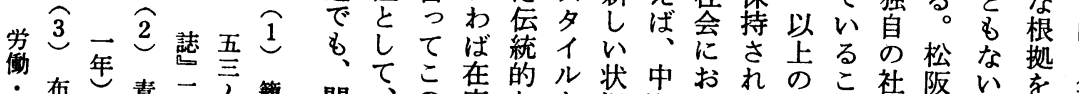

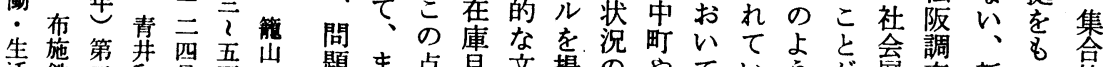
萿鉄章和号頁山題ま点貝文提のやていうが盧查新つ的

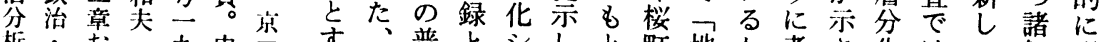

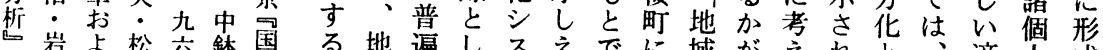

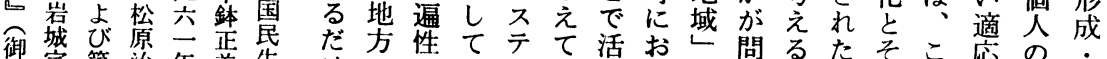

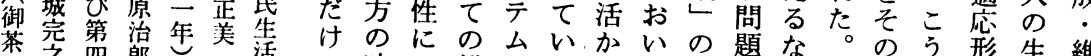

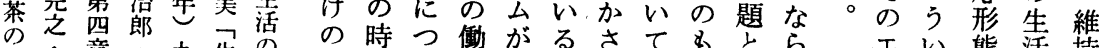

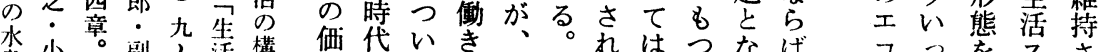

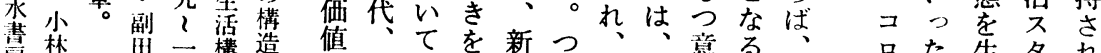

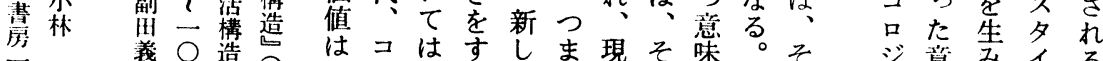

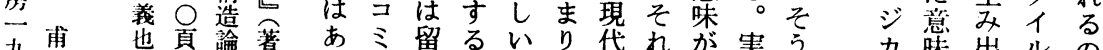

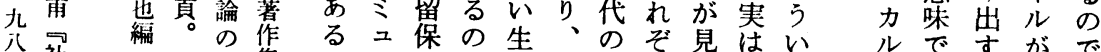

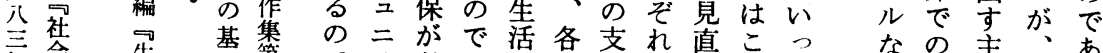

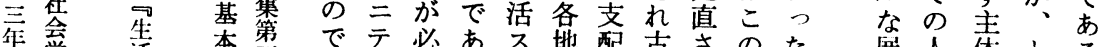

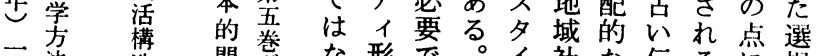
二法造問㗬な形で。イ社な伝るに択

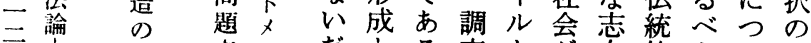

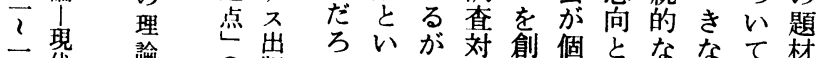

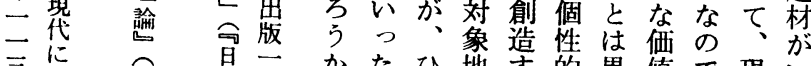

住有杲杂加たひ地专的異值で現い

真学分。思とのるになやあ代か

尘 潮う特う蓄つ行るのに と性え菜た事。都豊 関能らでて生がた算が

開令的きる。 にのなとこ 少主原しう な体動てし 加性力外た 5 が と的歴 ぬ松な条吏 影㭘な件的 響市る 与. 全 の本変集 えのあに的

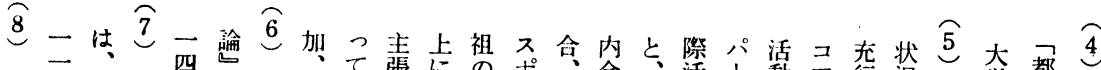

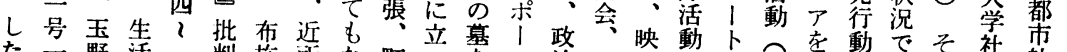

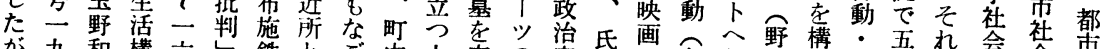

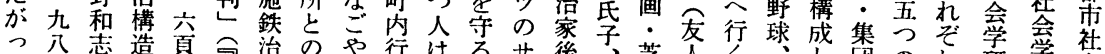

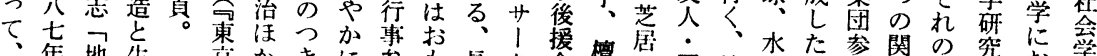

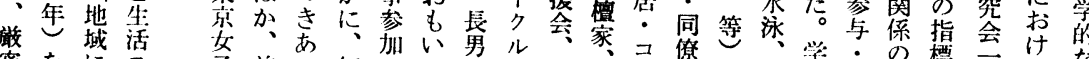

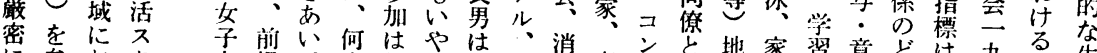

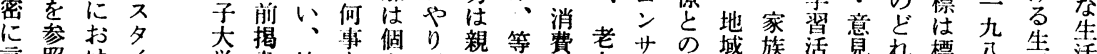

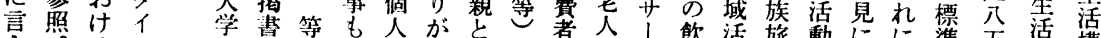

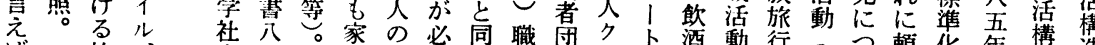

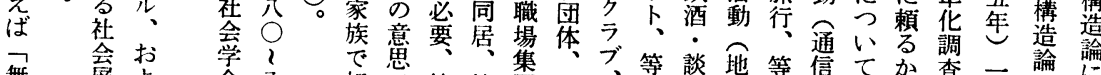

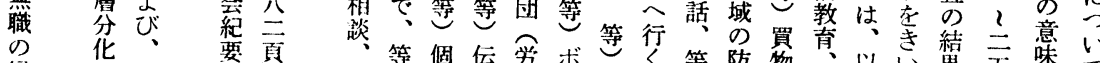

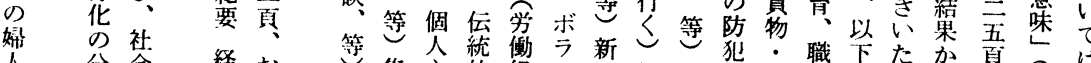

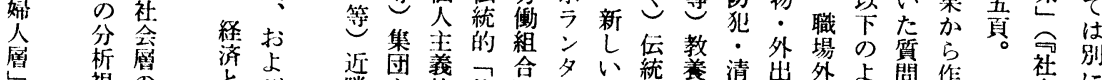

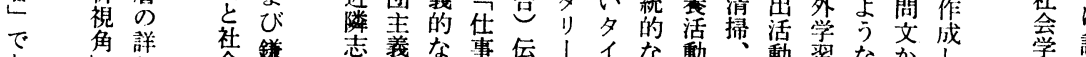

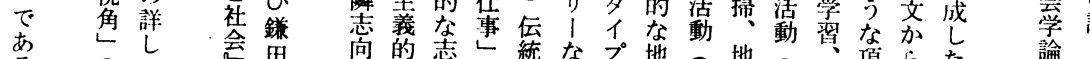

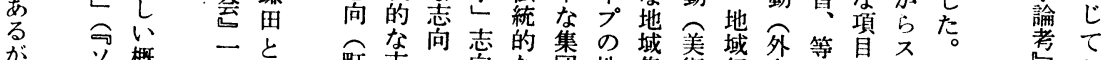

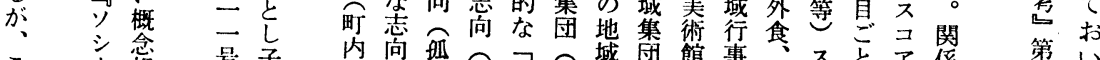

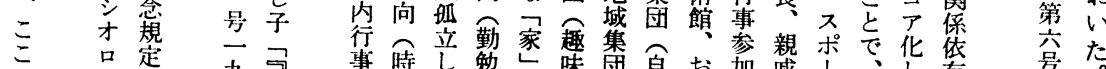

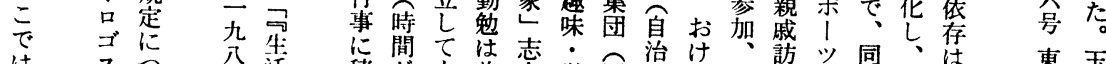

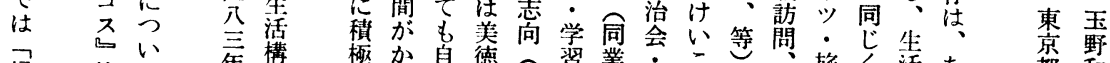

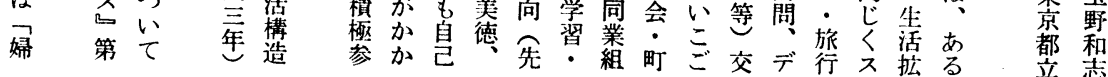


町別回収来

\begin{tabular}{|l|c|c|c|c|c|}
\hline & 中 町 & 新座町 & 内五曲町 & 桜 町 & 計 \\
\hline サンプル数 (人) & 76 & 53 & 74 & 130 & 333 \\
\hline 回収 票数 (票) & 59 & 39 & 49 & 94 & 241 \\
\hline 回 収 率 (\%) & 77.6 & 73.6 & 66.2 & 72.3 & 72.4 \\
\hline
\end{tabular}

回費 $\widehat{10} \widehat{9}$ 人

收援本層

等助調業上

汇查所略

以受は規さ

下模せ

のて都器て

と行立従 \&

おわ大業ら

り。扎查 。

を栭

の清

で志名

東標究带

東標帒收

京澼表入

陼华者 は

众查し收

総拿個、吾

含個文气

参别交方

揹接省で

究法の辛

助科分

手行学し 
a part of an effort to construct a more general theory of nationalism. In this view we first examine the concept of ideology from the view point of control in order to set it in the frame of the systems theory. Nationalism is characterized as one type of ideology.

In the second part of this paper, we characterize the 1950's in Quebec as a period of the coming of the traditional nationalism in question. Its inability to handle the problems caused by industrialization is the main reason for criticism. There are two currents which raise questions about the traditional nationalism: one is a negation of nationalism itself, the other is a renovation of nationalism. But politically, these two currents have a common enemy; that is, Duplessis government, in which they find an incarnation of traditional nationalism.

\title{
The Independence of "seikatsu-kôzô" (styles of life) and the significance of local areas
}

\author{
Kazushi Tamano \\ Tokyo Metropolitan Institute of Gerontology
}

Studies of "seikatsu-kôzô" in Japan have been emphasizing the significance of people's social life which is not totally dependent upon economic factors. In this field of study, however, there have not been sufficient discussions concerning an important question: what are the sociological bases to maintain the independence of social life? My purpose here is to give an answer to the question, based on a case study conducted in a consumer city of a traditional type. The data shows that the styles of residents' life are affected by the cultural system and the social organizations, which have been produced under the influence of the unique historical processes in the city. In this sense, we can understand the independence of " seikatsu-kôzô" only when we adopt a historical approach. The historical uniqueness of each local area is reproduced by the developement of the city itself, and is significant because it provides the diversity in styles of life which helps people create a new life-style against an industralist one.

\section{An Istitutional Study of Organization}

— A Critical Development of Luhmann's Theory of Organization -

Toshio Okuyama

Tokyo Uuiversity

Most of the theories of organization have causally explained the performance 